\title{
Analisis Normalized Difference Vegetation Index pada Unmanned Aerial Vehicle untuk Identifikasi Pertumbuhan Tanaman Padi di Kabupaten Aceh Besar Provinsi Aceh
}

\author{
Marwan Marwan ${ }^{a^{*}}$, Freddy Sapta Wirandhaa, Mayriska Husnaa, Cut Oktavia Saria, \\ Nizzamuddin ${ }^{b}$, Muhammad Yanis ${ }^{a}$ \\ a Teknik Geofisika, Fakultas Teknik, Universitas Syiah Kuala \\ b Jurusan Informatika, Fakultas Matematika dan Ilmu Pengetahuan Alam, Universitas Syiah Kuala \\ *Email : marwan.geo@unsyiah.ac.id
}

(Diterima 12 Juli 2021; Disetujui 2 Desember 2021; Dipublikasikan 29 Desember 2021)

\begin{abstract}
Abstrak
Teknologi unmanned aerial vehicle (UAV) berkembang pesat saat ini untuk berbagai kebutuhan, termasuk dalam bidang pertanian. Salah satu pemanfaatan UAV dalam bidang pertanian yaitu untuk mengamati tingkat kesuburan tanaman padi (Oryza sativa L). UAV mampu menerbangkan berbagai jenis kamera dan sensor, salah satunya adalah sensor normalized difference vegetation index (NDVI) mapir survey 3. Sensor NDVI ini menghasilkan nilai multispektral yang digunakan untuk menghitung selisih indeks vegetasi yang ternormalisasi. Nilai indeks vegetasi tersebut mencerminkan tingkat kesuburan tanaman padi. Tujuan dari penelitian ini untuk mengklasifikasikan tingkat kesuburan tanaman padi secara cepat dengan menggunakan metode unsupervised dan memperoleh luas lahan masing-masing indeks vegetasi yang telah dikelaskan. Tahapan awal penelitian ini adalah melakukan pengambilan data NDVI dengan menggunakan UAV yang telah terpasang sensor NDVI. Hasil foto udara tersebut digabungkan dengan proses mozaik citra dan klasifikasi kelas hasil analisis NDVI. Tahap akhir adalah melakukan klasifikasi hasil analisis NDVI untuk menghitung luasan daerah atau lahan masing-masing kelas NDVI. Hasil klasifikasi unsupervised menunjukkan 4 indeks kelas yaitu kelas indeks non vegetasi dengan nilai NDVI yaitu $-0,51$ hingga -1 dan luas lahan 1,462845 $\mathrm{Ha}$, kelas vegetasi rendah dengan nilai NDVI yaitu $-0,5$ hingga $-0,01$ dan luas lahan $3,412978 \mathrm{Ha}$, kelas vegetasi sedang dengan nilai NDVI 0,01 hingga 0,49 memiliki luas lahan 4,589696 Ha dan kelas vegetasi tinggi dengan nilai NDVI 0,51 hingga 1 memiliki luas lahan 5,744039 Ha.
\end{abstract}

Kata kunci: NDVI, UAV, Klasifikasi

\section{Latar Belakang}

Padi (Oryza Sativa L) merupakan salah satu makanan pokok penduduk Indonesia, sehingga padi menjadi kebutuhan utama masyarakat Indonesia. Oleh karena itu, Indonesia merupakan salah satu negara dengan tingkat produksi padi tertinggi nomor tiga di dunia, dengan jumlah produksi 70,8 juta ton per tahun. Salah satu daerah di Indonesia yang memproduksi padi paling banyak adalah Aceh. Aceh mempunyai luas lahan untuk memproduksi padi pada tahun 2019 sekitar 310 ribu hektar [1].

Pada masa pandemi global COVID-19, produktivitas sumber daya manusia berkurang, sehingga terjadi penurunan tingkat produksi padi secara umum di Indonesia dan khususnya daerah Aceh. Ditambah lagi dengan metode pertanian padi di Indonesia yang rata-rata masih menggunakan metode tradisional dan alat manual, termasuk dalam mengidentifikasi pertumbuhan dan perkembangan kesehatan tanaman padi, membuat produksi padi menurun.

Unmanned aerial vehicle (UAV) adalah salah satu teknologi yang sudah banyak digunakan dalam dunia pertanian terutama sebagai fungsi pengamatan dan penyiraman padi [2]. Dengan menggunakan UAV, pengamatan tumbuhan dapat dilakukan dengan waktu lebih cepat dan memakan biaya yang relatif lebih rendah. Ukuran UAV yang kecil membuatnya dapat bermanuver lebih banyak sehingga membuat pemotretan lahan lebih mudah dan cepat [3]. UAV merupakan sebuah sistem elektro-mekanik yang dikontrol tanpa awak. UAV dapat menjalankan misi terbang yang sudah terprogram maupun secara manual [4] dan merupakan wahana yang dilengkapi sistem pengendali terbang melalui gelombang navigasi presisi (GPS), dan elektronik kontrol penerbangan sehingga mampu terbang sesuai perencanaan 
terbang (autopilot)[5]. UAV dalam misi penerbangannya bisa membawa berbagai macam kamera dan sensor, salah satunya adalah sensor normalized difference vegetation index (NDVI).

NDVI adalah sebuah metode untuk mengamati keadaan vegetasi memanfaatkan fenomena fisik pantulan gelombang cahaya yang berasal dari dedaunan. Nilai kehijauan vegetasi suatu wilayah yang diamati berupa skala antara -1 (minimum) hingga 1 (maksimum) yang diperoleh dengan membandingkan reflektansi vegetasi yang diterima oleh sensor pada panjang gelombang merah (RED) dan inframerah dekat (NIR) [6]. Kemampuan NDVI untuk mendeteksi kondisi suatu vegetasi membuat metode ini sering digunakan dalam bidang pertanian.

Penelitian sebelumnya yang menggunakan UAV NDVI dalam pemanfaatan pemetaan ialah pemetaan desa dengan citra foto udara, pemetaan batas dan wilayah desa [7]. Dalam bidang mitigasi bencana, UAV digunakan untuk pemetaan bencana di daerah pesisir pantai dan jalur evakuasi bencana $[8,9]$. Dalam bidang pemetaan tanah, UAV digunakan untuk pemetaan bidang tanah pemukiman dalam skala besar [10]. Dalam bidang pertanian, UAV dimanfaatkan untuk menilai tingkat kesehatan, membuat estimasi produktivitas tanaman padi, memetakan tingkat produksi tanaman padi, dan menganalisis fase tumbuh tanaman padi $[11,12]$.

Penelitian ini dilakukan untuk mengklasifikasi tingkat kesuburan tanaman padi secara cepat dengan metode unsupervised dan memperoleh luas lahan masing-masing indeks vegetasi yang telah dikelaskan dengan menggunakan data perekaman sensor NDVI dengan memanfaatkan UAV.

\section{Metodologi}

Analisis tingkat kesuburan tanaman padi pada kawasan Aceh Besar diawali dengan pengambilan data lapangan dengan drone DJI Phantom4. Penggabungan citra foto menggunakan perangkat lunak Agisoft photoscan dengan metode mozaik citra, align photo, build dense cloud, dan build orthophoto. Analisis NDVI dengan metode unsupervised classification menggunakan perangkat lunak ENVI dan perhitungan luas lahan tiap kelas menggunakan perangkat lunak Arcgis 10.7.

a. Pengambilan data lapangan

Perekaman data citra dilakukan menggunakan drone DJI Phantom4 dengan berat 1,38 kg, ketinggian hingga $5 \mathrm{~km}$, dan waktu penerbangan maksimum 30 menit per satu baterai. Dilengkapi Kamera RGB dengan resolusi 20 megapiksel, drone ini mampu mengambil foto dan video. Setiap gambar ditandai dengan GPS yang memberikan informasi seperti lintang dan bujur serta ketinggian saat pengambilan data [13].

Proses perekaman data dilakukan menggunakan sensor NDVI yaitu MAPIR Survey 3 yang dihubungkan dengan DJI Phantom4 untuk mendapatkan data multispektral. Data multispektral digunakan untuk menghitung selisih indeks vegetasi (NDVI) yang ternormalisasi menggunakan persamaan umum digunakan untuk data citra satelit seperti yang ditunjukkan pada persamaan (1) [14].

$$
N D V I=\frac{N I R-R e d}{N I R+R e d}
$$

dengan NIR merupakan pantulan dari band inframerah dekat dan Red merupakan pantulan dari band merah.

\section{b. Penggabungan Citra}

Mozaik merupakan proses penggabungan foto menjadi satu kesatuan. Penggabungan dilakukan berdasarkan kesamaan koordinat dan kemiripan dengan objek (Gambar 1). Proses mozaik dilakukan mulai dari adding photo, align photo, build dense point cloud, dan build orthophoto.

Pada saat pemotretan udara di lapangan, posisi kamera tidak lepas dari adanya noise dan letak hasil foto seperti tilt displacement dan tip displacement. Pada tahap inilah proses align photo dilakukan dengan menggunakan perangkat lunak Agisoft photoscan untuk memperbaiki posisi gambar secara otomatis agar mendapatkan hasil akhir berupa point cloud. Perangkat lunak Agisoft photoscan juga menghitung perkiraan informasi ketinggian dari setiap penerbangan. Informasi ini untuk dikombinasikan ke dalam satu point cloud yang padat. Proses ini yang disebut sebagai build dense point cloud. Untuk hasil yang lebih detail dan data yang lebih akurat dibutuhkan waktu yang sedikit lebih lama.

Orthophoto adalah foto obyek pada posisi ortografi yang sudah dikoreksi secara geometri. Orthophoto memiliki ketelitian geometri yang sangat baik dan menyajikan ketampakan secara selektif. Build orthophoto dapat dibentuk setelah tahap pembuatan dense point clouds, mesh dan DEM yaitu ketika foto dari hasil data DEM telah dikoreksi kesalahan geometriknya. 


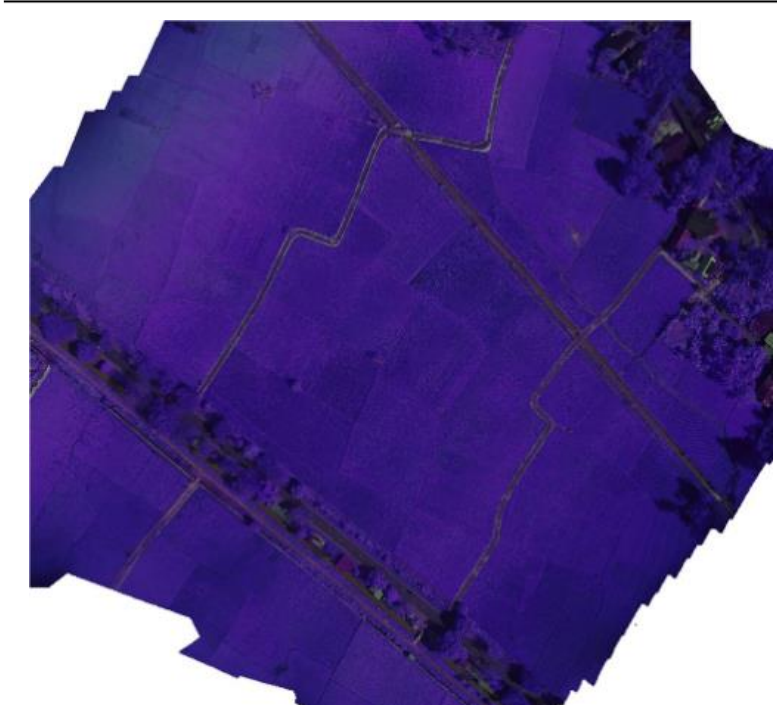

Gambar 1. Hasil mozaik citra yang dihasilkan dari pemotretan menggunakan UAV.

\section{c. Analisis NDVI}

Analisis NDVI dilakukan dengan menggunakan metode unsupervised classification. Proses ini dilakukan secara otomatis dengan perangkat lunak ENVI untuk mendapatkan nilai indeks vegetasi pada persamaan 1 yang kemudian digunakan untuk perhitungan luas lahan masingmasing kelas NDVI.

\section{d. Perhitungan Luas Lahan}

Perhitungan luas lahan tiap klasifikasi dilakukan dengan menggunakan perangkat lunak ArcGis menggunakan nilai indeks vegetasi. Luas lahan dihitung dengan satuan Hektar.

\section{Hasil dan Pembahasan}

\section{a. Hasil Analisis dan Klasifikasi NDVI}

Secara umum, vegetasi sehat akan memantulkan gelombang inframerah dekat dengan persentase yang lebih tinggi jika dibandingkan dengan vegetasi yang tidak sehat. Sebaliknya, gelombang visible akan dipantulkan lebih tinggi pada vegetasi tidak sehat dan lebih rendah pada vegetasi yang sehat. Nilai perhitungan NDVI yang semakin dekat dengan +1 dideteksi sebagai vegetasi sehat sedangkan perhitungan yang menghasilkan nilai yang kurang dari +1 atau jauh dari +1 dideteksi sebagai vegetasi tidak sehat, karena nilai dari suatu indeks vegetasi berupa +1 sebagai vegetasi dan -1 sebagai non-vegetasi [15]. NDVI pada tanaman padi dapat dilihat dari tingkat vegetasinya, semakin aktif proses fotosintesisnya maka nilai NDVI akan semakin tinggi. Sebaliknya, semakin rendah proses fotosintesis tanaman padi, maka nilai NDVI semakin rendah.
Berdasarkan Gambar 2, dapat dilakukan analisis sebagai berikut: warna biru menunjukkan klasifikasi wilayah non vegetasi, warna merah menunjukkan klasifikasi nilai NDVI yang sangat rendah yang diakibatkan oleh kurangnya proses fotosintesis pada wilayah tersebut, warna kuning menunjukkan klasifikasi nilai NDVI sedang yang artinya zat hijau daun pada daerah tersebut belum bekerja maksimal, warna hijau menunjukkan klasifikasi nilai NDVI bagus dan proses fotosintesis sempurna, warna ungu menunjukkan kawasan yang tidak mempunyai vegetasi seperti rumah, jalan, irigasi, dan lain sebagainya. Wilayah dengan warna merah dan warna kuning menunjukkan pertumbuhan padi yang kurang bagus dan biasanya disebabkan oleh hama atau penyebab lainnya yang menghambat pertumbuhan tanaman padi. Wilayah warna ungu menunjukkan nilai NDVI dekat -1 sampai -1. Wilayah berwarna merah dan berwarna kuning menunjukkan nilai NDVI yang kurang dari +1 atau jauh dari +1 yang dideteksi sebagai vegetasi tidak sehat. Warna hijau menunjukkan nilai indeks vegetasi yang baik, menunjukkan wilayah tersebut memiliki nilai NDVI berada pada +1 . Tanaman padi yang berada di daerah tersebut memiliki proses fotosintesis yang baik. Nilai NDVI tanaman padi dapat dilihat pada Tabel 1.

Tabel 1. Nilai NDVI tanaman Padi

\begin{tabular}{|l|l|l|}
\hline No & Kelas NDVI & \multicolumn{1}{|c|}{ Nilai NDVI } \\
\hline 1 & Non vegetasi & $-0,51$ hingga -1 \\
\hline 2 & NDVI Rendah & $-0,5$ hingga $-0,01$ \\
\hline 3 & NDVI Sedang & 0,01 hingga 0,49 \\
\hline 4 & NDVI Tinggi & 0,51 hingga 1 \\
\hline
\end{tabular}

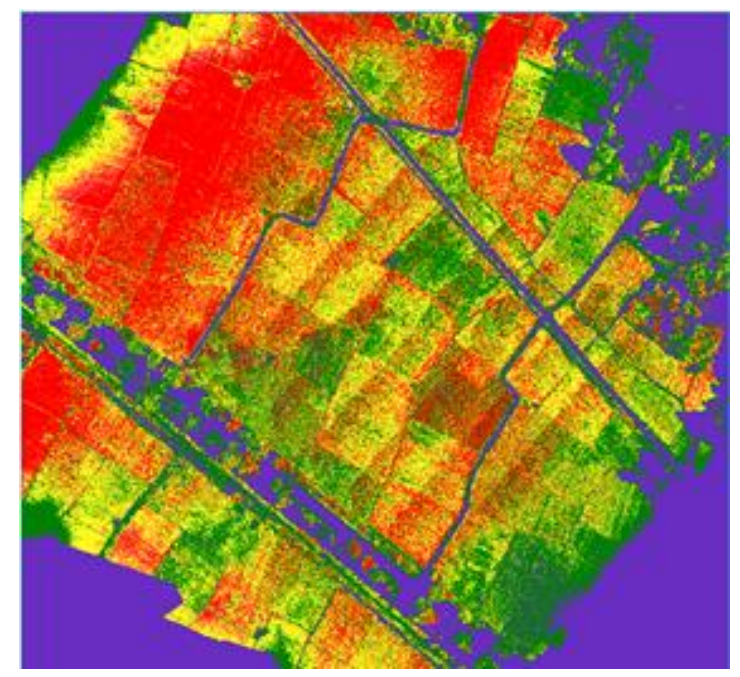

Gambar 2. Hasil analisis normalized different vegetation index (NDVI) 
b. Luas Lahan

Berdasarkan Tabel 2 luasan daerah berdasarkan kelas NDVI dapat dibagi dalam empat kelas. Kelas pertama adalah non-vegetasi berwarna ungu yang memiliki luas lahan 1,462845 Ha. Kelas kedua NDVI rendah yang berwarna merah yang memiliki luas lahan 3,412978 Ha. Kelas ketiga merupakan NDVI sedang berwarna kuning dengan luasan lahannya adalah 4,589696 Ha. Kelas keempat merupakan NDVI tinggi berwarna hijau yang memiliki luas lahan 5,744039 Ha.

Tabel 2. Hasil perhitungan Luas Lahan.

\begin{tabular}{|l|l|c|}
\hline No & Kelas NDVI & Nilai NDVI (Ha) \\
\hline 1 & Non Vegetasi & 1,462845 \\
\hline 2 & NDVI Rendah & 3,412978 \\
\hline 3 & NDVI Sedang & 4,589696 \\
\hline 4 & NDVI Tinggi & 5,744039 \\
\hline
\end{tabular}

\section{Kesimpulan}

Berdasarkan hasil analisis dan pembahasan yang telah disajikan tersebut dapat disimpulkan bahwa nilai multispektral dari sensor NDVI dapat memetakan tingkat kesuburan tanaman padi dengan baik. Metode klasifikasi unsupervised menghasilkan 4 kelas NDVI dan luasan masingmasing kelas yaitu non vegetasi dengan rentang nilai -0,51 hingga -1 dan luas lahan 1,462845 $\mathrm{Ha}$, vegetasi rendah dengan rentang nilai NDVI -0,5 hingga -0,01 dan luas lahan 3,412978 $\mathrm{Ha}$, vegetasi sedang dengan rentang nilai NDVI 0,01 hingga 0,49 dan luas lahan 4,589696 $\mathrm{Ha}$, serta vegetasi tinggi dengan rentang nilai NDVI 0,51 hingga 1 dan memiliki luas lahan 5,744039 Ha.

\section{Daftar Pustaka}

[1] Fitasari, W, Useng, D, dan Munir, A., Pendugaan Produksi Dan Indeks Vegetasi Tanaman Padi Menggunakan Data Citra Platform Unmanned Aerial Vehicle (UAV) Dan Data Citra Satelit Landsat 8, Journal Agritechno, 10(2), pp. 203216, 2017.

[2] Hidayat, R., Rancang Bangun Prototype Drone Penyemprot Pestisida Untuk Pertanian Padi Secara Otomatis, Jurnal Tektro, 3(2), pp. 8694, 2020.

[3] Afdhalia, F., Supriatna, dan Shidiq, I. P. A., Analisis Variasi Nilai Spektral Tanaman Padi Menggunakan Teknologi UAV, Seminar Nasional Penginderaan Jauh, pp. 512-518, 2019.

[4] Saroinsong, H. S., Poekel, V. C., Manembu, P. D., Rancang Bangun Wahana Pesawat Tanpa Awak (Fixed Wing) Berbasis Ardupilot, Jurnal Teknik Elektro dan Komputer, 7(1), pp. 73-84,
2018.

[5] Fernández, T., Pérez, J. L., Cardenal. J., Gómez, J. M., Colomo, C., dan Delgado, J., Analysis of landslide evolution affecting olive groves using UAV and photogrammetric techniques, Remote Sensing, 8(10), 2016.

[6] Faizal, A., dan Amran, M. A., Model Transformasi Indeks Prediksi Kerapatan Mangrove, Pertemuan Imiah Tahunan MAPIN XIV Pemanfaatan Ef. Penginderaan Jauh Untuk Peningkatan Kesejahteraan Bangsa, pp. 14-15, 2005.

[7] Bakar, M. A., Wirandha, F. S., Nizzamuddin, N., dan Susanta, F. F., Comparison of Accuracy Aerial Photography UAV (Unmanned Aerial Vehicle) and GNSS (Global Navigation Satelitte System) for Mapping of Lambarih Village, Aceh Besar, Aceh, J. Aceh Phys. Soc., 9(3), pp. 78-83, 2020.

[8] Pattiselanno, S. R. R., dan Soetrisno, A. K., Mitigasi dan pemetaan jalur alternatif evakuasi cepat lingkar kampus POLNAM untuk antisipasi potensi tsunami pasca gempa Ambon berbasis GIS dan foto udara, J. Simetrik, $10(2)$ pp. 362, 2021.

[9] Meiarti, R., Seto, T., dan Sartohadi, J., Uji Akurasi Hasil Teknologi Pesawat Udara Tanpa Awak (Unmanned Aerial Vehicle) Dalam Aplikasi Pemetaan Kebencanaan Kepesisiran, Jurnal Geografi. Edukasi dan Lingkungan, 3(1) p. 1, 2019.

[10] Adi, A., Yudo, P., dan Yuwono, B. D., Pengujian Akurasi dan Ketelitian Planimetrik pada Pemetaan Bidang Tanah Pemukiman Skala Besar Menggunakan Wahana Unmanned Aerial Vehicle (UAV), Jurnal Geodesi Undip, 6(1), pp. 208-217, 2017.

[11] Wahyunto, Widagdo, dan Heryanto. B., Pendugaan Produktivitas Tanaman Padi Sawah Melalui Analisis Citra Satelit, Informatika Pertanian, 15, pp. 853-869, 2006.

[12] Yuniarto, A., Prasetyo, Y., dan Haniah, H., Analisis Tingkat Produktivitas Padi Berdasarkan Metode NDVI (Normalized Difference Vegetation Index) dan LSWI (Land Surface Water Index) Menggunakan Citra Landsat Tahun 2007 Dan 2009 (Studi Kasus : Kabupaten Karanganyar, Jawa Tengah), Jurnal Geodesi Undip, 4(3), pp. 26-34, 2015.

[13] Marwan, Idroes, R., Yanis, M., Idroes, G. M., dan Syahriza, A Low-Cost UAV Based Application for Identify and Mapping a Geothermal Feature in Ie Jue Manifestation, Seulawah Volcano, Indonesia, International Journal of GEOMATE, 20(80), pp. 135-142, 2021.

[14] Guan, S., Fukami, K., Matsunaka, H., Okami, M., Tanaka, R., Nakano, H., Sakai, T., Nakano, K., Ohdan, H., Takahashi, K., Assessing correlation of high-resolution NDVI with fertilizer 
POSITRON Vol. 11, No. 2 (2021), Hal. 121 - 125

application level and yield of rice and wheat crops using small UAVs, Remote Sensing, 11(2), pp. 112, 2019.

[15] Suab, S. A., Syukur, M. S., Avtar, R., dan Korom, A., Unmanned Aerial Vehicle (UAV) Derived Normalised Difference Vegetation Index (NDVI) and Crown Projection Area (CPA) To
Detect Health Conditions of Young Oil Palm Trees for Precision Agriculture," ISPRS - Int. Arch. Photogramm. Remote Sens. Spat. Inf. Sci., XLII-4/W16, pp. 611-614, 2019. 